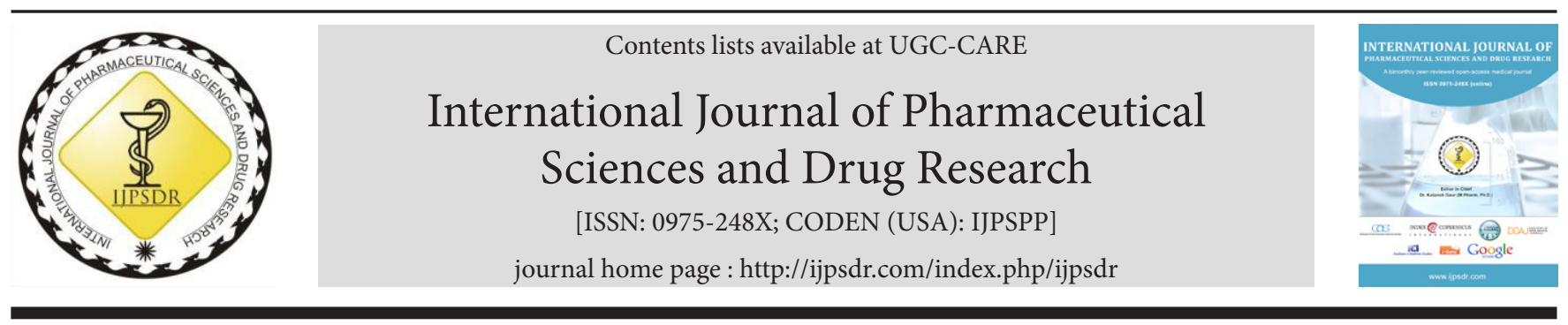

Research Article

\title{
In vivo and In vitro Antidiabetic Characterization of Nymphaea alba Leaves
}

\author{
Gurvirender Singh $^{1}$, Supriya Agnihotri ${ }^{2 *}$, Santosh Kumar Verma ${ }^{3}$ \\ ${ }^{1}$ I. K. Gujral Punjab Technical University, Kapurthala-144603, Punjab, India \\ ${ }^{2}$ Chandigarh College of Pharmacy, Chandigarh Group of Colleges, Landran-140307, Punjab, India \\ ${ }^{3}$ MotherHood University, Roorkee-247661, Uttarakhand, India
}

\begin{tabular}{l} 
A R T I C L E I N F O \\
\hline Article history: \\
Received: 10 July, 2020 \\
Revised: 18 August, 2020 \\
Accepted: 30 August, 2020 \\
Published: 30 September, 2020 \\
Keywords: \\
Antioxidant, \\
Hyperglycemia, In vitro, \\
Nymphaea alba, \\
Streptozotocin. \\
DOI: \\
10.25004/IJPSDR.2020.120520
\end{tabular}

\section{INTRODUCTION}

Today's modern society is facing a variety of health issues and diabetes mellitus is one of them. It is considered a metabolic disorder, diagnosed by an increase in blood glucose levels. ${ }^{[1]}$ It is associated with the deregulation of insulin production or secretion or depletion of cellular responses for insulin stimulus. ${ }^{[2]}$ This could be due to abnormality of insulin receptors, signal transducer system, effecter enzymes, or genes. ${ }^{[3]}$ Diabetes mellitus has been a threat to mankind from very old times. The evidence of its historical existence was reported in the Egyptian manuscript three thousand years ago, ${ }^{[4,5]}$ and now it a global issue, recent research reports that diabetes mellitus ubiquity is exponentially rising throughout the

\begin{abstract}
A B S T R A C T
The study was aimed to trace out antihyperglycemic potentials of Nymphaea alba leaves, using in vitro and in vivo approaches. In in vitro study, determination of $\mathrm{IC}_{50}$ of $N$. alba extracts was done using $\alpha$-amylase inhibition of $56.77 \pm 1.23 \%$ at $125 \mu \mathrm{g} / \mathrm{mL}$, in comparison to $66.7 \pm 0.94 \%$ of standard acarbose. In in vivo study was performed on diabetic rats, made diabetic by streptozotocin (STZ). A 200 and $400 \mathrm{mg} / \mathrm{kg}$ NAME was administered orally, which significantly $(\mathrm{p}<0.001)$ reduces blood glucose of treated animals in contrast to diabetic control. A distinguishable linear rise of body weight and high-density lipoprotein (HDL) was observed, while there was a remarkable reduction in cholesterol, triglycerides (TG), low-density lipoprotein (LDL), and very low-density lipoprotein (VLDL). Reduction in liver function serum glutamicoxaloacetic transaminase (SGOT), serum glutamic-pyruvic transaminase (SGPT) with serum creatinine, and urea results was also observed in contrast to diabetic control rats. A $400 \mathrm{mg} / \mathrm{kg}$ of NAME reflected the most significant results in comparison to that of standard. In addition, an antioxidant study of all three extracts of $N$. alba was done by 2,2-diphenyl-1-picrylhydrazyl (DPPH) and $\mathrm{H}_{2} \mathrm{O}_{2}$ assay. Methanol extracts were found to possess the highest antioxidant capacity among chloroform and petroleum ether extracts. The whole study gives insight that NAME probably has antidiabetic potentials.
\end{abstract}

\footnotetext{
${ }^{*}$ Corresponding Author: Supriya Agnihotri

Address: Chandigarh College of Pharmacy, Chandigarh Group of Colleges, Landran-140307, Punjab, India

Email $\bowtie$ : asupriya149@gmail.com

Tel.: +91-9896091945

Relevant conflicts of interest/financial disclosures: The authors declare that the research was conducted in the absence of any commercial or financial relationships that could be construed as a potential conflict of interest.

Copyright (C) 2020 Gurvirender Singh et al. This is an open access article distributed under the terms of the Creative Commons AttributionNonCommercial-ShareAlike 4.0 International License which allows others to remix, tweak, and build upon the work non-commercially, as long as the author is credited and the new creations are licensed under the identical terms.
}

world. ${ }^{[6]}$ Although, diabetes can be treated by several therapeutic approaches, yet no such drug has been identified which can provide complete relief without side effects. ${ }^{[7,8]}$ Incorporation of traditional medicinal plants has always been an imperative tool in drug discovery. ${ }^{[9]}$ The hypoglycemic potential of numerous plants, used in diabetes treatment, has been proved already. ${ }^{[10]}$ Plants derived formulations have lower toxicity and side effects in contrast to synthetic drugs. ${ }^{[11,12]}$ Furthermore, taking care of World Health Organisation (WHO) recommendation on diabetes mellitus, it becomes necessary to investigate the hypoglycemic potentials of medicinal plants. ${ }^{[13]}$ Therefore, documentation and validation of antidiabetic therapeutic efficacy of medicinal plants, as well as, characterization of phytoconstituents is increasing. ${ }^{[14]}$ 
The genus Nymphaea comprises about forty-fifty species, ${ }^{[15]}$ out of which five species are present in India. ${ }^{[16]} N$. alba belongs to the Nymphaeaceae family. $N$. alba is frequently referred to as "European White Water Lily or Nenuphar."[17] It is a perennial hydrophyte having a black, sturdy, almost horizontal, and scarcely branched rhizome submerged in the mud. ${ }^{[17]}$ It grows at depth of about 0.5 to 3 meters, in water over mud, silt, or peat. ${ }^{[17-20]}$ It spreads extensively throughout Europe, North Africa, north and central Asia, southwest Asia, Finland, India, China, Russia, Turkey, and Poland. ${ }^{[21]}$ $N$. alba has a history of ethnobotanical applications in different cultures. ${ }^{[22-24]}$ Other species of Nymphaea are known to possess potent antidiabetic properties. Moreover, as no scientific evidence of antidiabetic activity is there in $N$. alba leaves; the present study was carried to trace out its hidden antidiabetic potentials. A collaborated approach, including in vivo and in vitro techniques, was employed for the exploration of the antidiabetic properties of $N$. alba in the current research work.

\section{Materials AND Methods}

\section{Animals}

Wistar rats were incorporated into the study (180 \pm 20 grams). Proper hygiene and sanitation were maintained for animals. Normal conservation conditions provided in clean polypropylene cages at $23 \pm 1^{\circ} \mathrm{C}$, equal hours light:dark period, and relative humidity were regulated at $60 \pm 4 \%$. Normal animal feed with water was maintained. The animals had been acclimatized to the laboratory environment prior to the start of the experimentation. ${ }^{[25]}$ Guidelines provided for animal care and experimentations were followed throughout the period. The experimental protocol was accepted by the Institutional Animal Ethics Committee (IAEC) at M. M. College of Pharmacy, M. M. U. Mullana (IAEC/19/20).

\section{Plant Collection and Authentication}

Plant material was collected during July-September from crocodile breeding park Kurukshetra. It was authenticated by Dr. B. D. Vashishta, Botany Department, Kurukshetra University, Haryana, India.

\section{Extracts Preparation}

After shade drying, plant material was coarsely powdered and then successively extracted using different solvents with increasing polarity in the Soxhlet apparatus. Initially, pet-ether $\left(60-70^{\circ} \mathrm{C}\right)$ was used to remove fats from the plant material, as extracts containing lipid content cause hindrance in the spectroscopic evaluation of isolated compound, followed by extraction with chloroform and methanol. The whole extraction procedure was carried at the same temperature. After the collection of the extracts, a rotary evaporator was then employed to concentrate them, so that a concentrated crude mass can be formed for further study.

\section{In vitro Studies}

\section{$\alpha$-Amylase Activity}

To investigate the amylase inhibitory potential of all the three extracts of N. alba, $\alpha$-amylase inhibition assay was used, the method followed as per Ali et al., with some alterations. In brief, $30 \mu \mathrm{L}$ of varying concentrations of plant extracts that is $8,15,30,60$, and $125 \mu \mathrm{g} / \mathrm{mL}, 200 \mu \mathrm{L}$ alpha-amylase was added, followed by incubation for 20 minutes at $37^{\circ} \mathrm{C}$. Then, the addition of $100 \mu \mathrm{L}$ of the $(1 \%)$ starch solution was done and again subjected to incubation for 10 minutes at $37^{\circ} \mathrm{C}$. To stop the reaction, $200 \mu \mathrm{L}$ 3,5-dinitrosalicylic acid (DNSA) was added. Readings were taken at $540 \mathrm{~nm}$ wavelength. ${ }^{[26,27]}$ Acarbose was taken as standard. To enhance the reproducibility and resolution of the results, experiments were repeated thrice using the same protocol.

\section{$\alpha$-Glucosidase Activity}

In the $\alpha$-glucosidase assay, $95 \mu \mathrm{L}$ of the phosphate buffer $(100 \mathrm{mM})$ was added to 96 -well microplates. $25 \mu \mathrm{L}$ of the alpha-glucosidase $(0.5 \mathrm{U} / \mathrm{mL})$ was added, and then $30 \mu \mathrm{L}$ of plant extracts $(8,15,30,60$, and $125 \mu \mathrm{g} / \mathrm{mL})$ and acarbose in the same concentrations were added. Acarbose was taken as a standard for the experiment. Then, the above reaction mixtures were subjected to incubation for 20 minutes at $37^{\circ} \mathrm{C}$. After incubation, $50 \mu \mathrm{L}$ of $5 \mathrm{mM}$ p-nitrophenyl-D-glucopyranoside (p-NPG) was added and subjected to incubation for 10 minutes at $37^{\circ} \mathrm{C}$. A $2 \mathrm{~mL}$ of $\mathrm{Na}_{2} \mathrm{CO}_{3}(0.1 \mathrm{M})$ was added for termination of the reaction. ${ }^{[28,29]}$ Absorbance was taken at $415 \mathrm{~nm}$, using iMark microplate reader. The quantity of alphanitrophenol released from p-NPG was used to estimate percent inhibition.

$\%$ inhibition $=100 \times$ Absorbance of control - Absorbance of sample/Absorbance of control

\section{Antioxidant Activity}

\section{DPPH Antioxidant Assay}

DPPH stock solution was made by mixing $3.3 \mathrm{mg}$ of DPPH in $100 \mathrm{~mL}$ of methanol. $1 \mathrm{~mL}$ of different concentrations of the test solution $(8,15,30,60$, and $125 \mu \mathrm{g} / \mathrm{mL})$ was put in $2.5 \mathrm{~mL}$ of stock solution. After keeping for half an hour, readings were taken at $517 \mathrm{~nm}$ in an ultraviolet-visible (UV) spectrophotometer in contrast to the standard at varying concentrations $(2,4,6,8 \text {, and } 10 \mu \mathrm{g} / \mathrm{mL})^{[30]}$ Ascorbic acid was taken as a reference. The calculation was done using the formula given below.

$\%$ inhibition $=100 \times$ Absorbance of control - Absorbance of sample/Absorbance of control

\section{Hydrogen Peroxide Assay}

For the evaluation, a solution was made by mixing hydrogen peroxide $(40 \mathrm{~mm})$ and phosphate buffer with $\mathrm{pH} 7.4$. to $0.6 \mathrm{~mL}$ of this solution, varying concentration $(25,50$, $100,200$, and $400 \mu \mathrm{g} / \mathrm{mL})$ of samples and $(10,20,40,60$, 
and $80 \mu \mathrm{g} / \mathrm{mL}$ ) standard was added. ${ }^{[31]}$ After 10 minutes, readings of hydrogen peroxide were taken at $230 \mathrm{~nm}$. Blank contained only buffer solution. The same abovementioned formula was employed to find the percentage inhibition of hydrogen peroxide in samples, as well as, standard compounds.

\section{In vivo Studies}

\section{Acute Toxicity Studies}

For the acute toxicity evaluation, the guidelines of the Organization of Economy and Cooperation Development (OECD 423) were followed. 8 to 12 weeks old albino mice weighing 20 to 30 grams were included for toxicity studies. Animals were fasted for 3 to 4 hours prior to dosing. After that, weighing of the animals was done followed by administration of the extracts using gastric intubation. ${ }^{[32,33]}$ Even after the administration of the extracts, animals were not provided any food for the next couple of hours. A dose of 2,000 mg/ $\mathrm{kg}$ was given to six animals initially. ${ }^{[34]}$ In the initial 30 minutes, animals were monitored independently, upon dosing, and periodically over 24 hours, out of which, the first four hours were considered crucial, hence, monitored vigilantly and regularly afterward for a duration of 14 days.

\section{Oral Glucose Tolerance Test (OGTT)}

Four groups of rats were made on a random basis, having six animals each. Animals were made to fast overnight. Normal control group-I animals were only administered with the vehicle; group-II animals were treated with $2.5 \mathrm{mg} / \mathrm{kg}$ of standard drug glibenclamide; groups III and IV received NAME $(200,400 \mathrm{mg} / \mathrm{kg})$ and served as test groups ${ }^{[35]}$ Rats of every group were administered with $2,000 \mathrm{mg} / \mathrm{kg}$ of glucose that is 30 minutes prior to the oral administration of the test and standard compounds. ${ }^{[36]}$ After 30, 60, and 120 minutes of oral glucose, blood was withdrawn from the tail on to the strip of glucometer, and concentrations of glucose in the blood was measured (using Accu-Chek, Roche Diagnostics, USA).

\section{STZ-induced Diabetic Study ${ }^{[37,38]}$}

A single dose of STZ (55 mg/kg) was administered intraperitoneally to the overnight fasted rats. Preparation of dose was carried spontaneously, using very cold citrate buffer with $\mathrm{pH}$ 4.5. Group-I animals were given no treatment or STZ throughout the study. For the next 12 days, animals were kept under observation with proper feed and water and on the 12th day, animals were screened for blood glucose. ${ }^{[39,40]}$ Animals were believed to have diabetes, if blood glucose levels were found to be $200 \mathrm{mg} / \mathrm{dL}$ or higher, and incorporated into the study.

\section{Experimental Design}

Five groups $(G)$ of rats were assigned, containing six rats $(n=6)$ each.
Group-I: Normal healthy rats administered 0.9 percent sodium chloride $(\mathrm{NaCl})$.

Group-II: Diabetic rats were given only 0.9 percent $\mathrm{NaCl}$. Group-III: Diabetic rats + glibenclamide $(2.5 \mathrm{mg} / \mathrm{kg})$.

Group-IV: Diabetic rats + NAME $(200 \mathrm{mg} / \mathrm{kg})$.

Group-V: Diabetic rats + NAME $(400 \mathrm{mg} / \mathrm{kg})$.

Both test and standard drugs were administered for the next 21 days and a dose of methanol extract of $N$. alba and glibenclamide were made in the vehicle solution $(0.9 \% \mathrm{NaCl})$ at room temperature.

\section{Biochemical Estimations}

For tracing blood glucose levels, a one-touch glucometer (Accuchek, Roche Diagnostics) was used at weekly intervals. After completion of the study, blood samples were procured in ethylenediaminetetraacetic acid (EDTA) tubes, by cardiac puncture, as well as, retro-orbital plexus method, from all animals. After that, for 20 minutes at $3,000 \mathrm{rpm}$ centrifugation of blood samples was done. Serum separation and storage at $-20^{\circ} \mathrm{C}$ was done till tests were performed. Determination of cholesterol, HDL, LDL, VLDL, triglycerides, urea, and creatinine were done from collected serum samples with the help of an autoanalyzer, using ERBA diagnostic kits.

\section{Histopathology}

Once the whole animal study was completed, the pancreas of dissected rats was fixed in $10 \%$ formalin solution, after rinsing in ice-cold normal saline. ${ }^{[41]}$ Further, tissues were subjected to embedding in paraffin wax. With the help of microtome, 4 to $5 \mu \mathrm{m}$ thick sections were made. For staining of the sections, hematoxylin-eosin was used. Stained tissues were examined under a light microscope.

\section{Statistical Analysis}

For tracing significant difference $(p<0.05)$, one-way analysis of variance (ANOVA) was applied and comparative analysis was done with Dunnet's t test in vivo studies, for instance, blood glucose, body weight, biochemical parameters, and in vitro inhibition assays. For the representation of results, the mean \pm standard error of the mean pattern was used.

\section{RESULTS}

\section{In vitro}

\section{$\alpha$-Amylase Activity}

Concentrations including $8,15,30,60$, and $125 \mu \mathrm{g} / \mathrm{mL}$ were used for screening of $N$. alba petroleum ether, chloroform, and methanol extract (Fig. 1). The NAME exhibited $\mathrm{IC}_{50}$ $74.56 \pm 1.872$ in comparison to $\mathrm{IC}_{50} 24.16 \pm 1.383$ of standard acarbose. $\mathrm{IC}_{50}$ of both other extracts of $N$. alba was found to be insignificant in comparison to $\mathrm{IC}_{50}$ of standard. 


\section{$\alpha$-Glucosidase Activity}

$N$. alba extracts were studied at $8,15,30,60$, and $125 \mu \mathrm{g} / \mathrm{mL}$ concentrations and NAME exhibited significant inhibition in comparison to standard acarbose, while $N$. alba chloroform extract (NACE) and N. alba petroleum

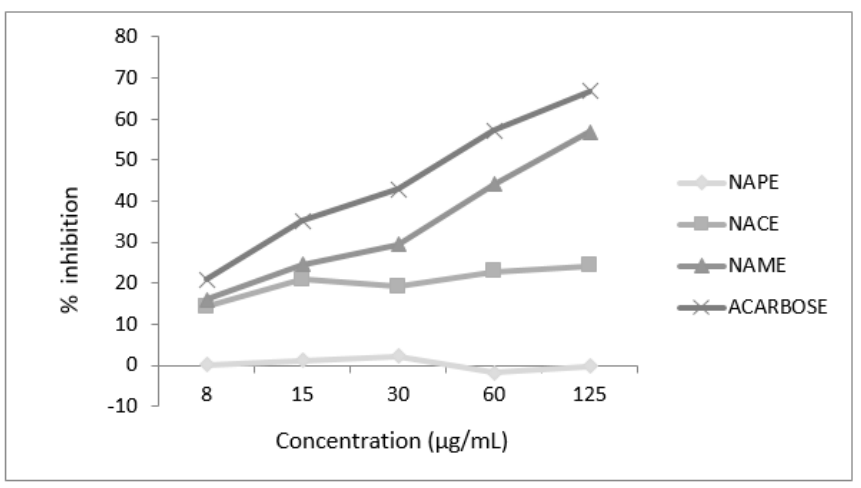

Fig. 1: $\alpha$-amylase inhibition activity of $N$. alba NAPE: N. alba petroleum extract; NACE: N. alba chloroform extract; NAME: N. alba methanol extract

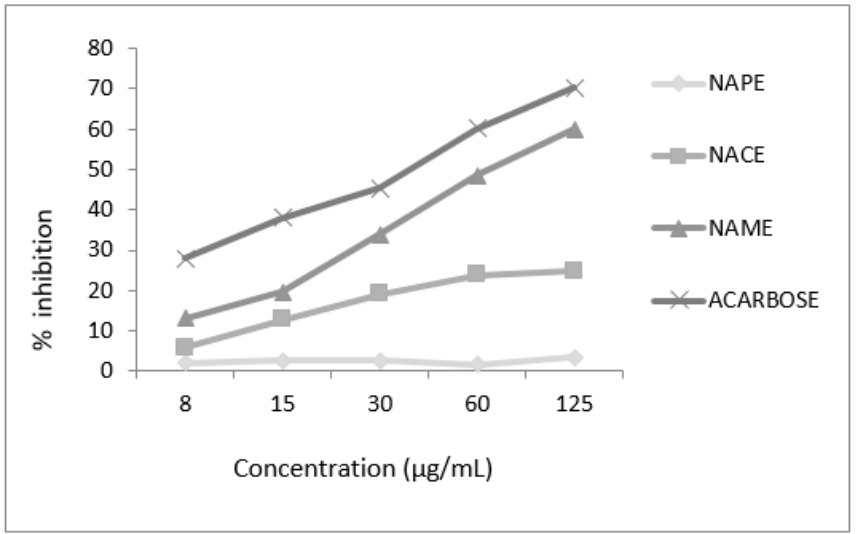

Fig. 2: $\alpha$-glucosidase inhibition activity of $N$. alba NAPE: N. alba petroleum extract; NACE: N. alba chloroform extract; NAME: N. alba methanol extract extract (NAPE) showed minimum inhibition (Fig. 2). With an increase in concentration, percentage inhibition was found to be increased. The maximum enzyme inhibition with standard drug, i.e., acarbose was $70.31 \pm 1.25$ at $125 \mu \mathrm{g} / \mathrm{mL}$.

\section{Antioxidant Activity}

\section{DPPH Assay for Radical Scavenging Activity}

In DPPH assay, NAME showed $63.97 \pm 0.62$ percent inhibition at $125 \mu \mathrm{g} / \mathrm{mL}$, while NAPE and NACE exhibit only $12.35 \pm 1.86$ and $41.39 \pm 1.86$, respectively. NAME exhibited comparable inhibition to that of standard ascorbic acid (Table 1).

\section{Hydrogen Peroxide Activity}

$N$. alba extracts at $25,50,100,200$, and $400 \mu \mathrm{g} / \mathrm{mL}$. The NAME showed good hydrogen peroxide radical scavenging activity when compared to standard ascorbic acid, which showed 79.91 percent inhibition at $400 \mu \mathrm{g} / \mathrm{mL}$ concentration, as shown in Table 2.

\section{In vivo}

\section{Toxicity Study}

No mortality was observed in all groups. No clinical signs were observed in selected animals for study. The overall study showed that $\mathrm{LD}_{50}$ of oral toxicity of extract to be above $2,000 \mathrm{mg} / \mathrm{kg}$ in mice of both sexes.

\section{Oral Glucose Tolerance Test (OGTT)}

The blood glucose concentration of group-I normal control rises significantly in comparison to groups III and IV. The mean blood glucose level after 30 minutes in group-I (normal control) was $145.71 \mathrm{mg} / \mathrm{dL}$ (Table 3). Oral administration of extracts and standard drug caused a comparable fall in blood glucose in contrast to the

Table 1: DPPH scavenging activity of extracts of N. alba

\begin{tabular}{llllll}
\hline Drug & $8 \mu \mathrm{g} / \mathrm{mL}$ & $15 \mu \mathrm{g} / \mathrm{mL}$ & $30 \mu \mathrm{g} / \mathrm{mL}$ & $60 \mu \mathrm{g} / \mathrm{mL}$ & $125 \mu \mathrm{g} / \mathrm{mL}$ \\
\hline NAPE & $1.24 \pm 0.36$ & $3.39 \pm 0.95$ & $4.11 \pm 1.29$ & $9.49 \pm 1.56$ & $12.35 \pm 1.86$ \\
NACE & $10.2 \pm 0.62$ & $16.66 \pm 0.62$ & $24.9 \pm 0.95$ & $35.65 \pm 1.29$ & $41.39 \pm 1.86$ \\
NAME & $24.9 \pm 1.56$ & $34.58 \pm 1.29$ & $46.41 \pm 0.95$ & $53.57 \pm 0.95$ & $63.97 \pm 0.62$ \\
\hline- & $2 \mu \mathrm{g} / \mathrm{mL}$ & $4 \mu \mathrm{g} / \mathrm{mL}$ & $6 \mu \mathrm{g} / \mathrm{mL}$ & $8 \mu \mathrm{g} / \mathrm{mL}$ & $10 \mu \mathrm{g} / \mathrm{mL}$ \\
\hline Ascorbic acid & $37.09 \pm 0.62$ & $44.25 \pm 0.36$ & $53.22 \pm 0.62$ & $66.12 \pm 0.62$ & $75.08 \pm 1.29$ \\
\hline
\end{tabular}

NAPE: N. alba petroleum ether extract; NACE: N. alba chloroform extract; NAME: N. alba methanol extract

Table 2: $\mathrm{H}_{2} \mathrm{O}_{2}$ scavenging activity of extracts of $N$. alba

\begin{tabular}{llllll}
\hline Drug & $25 \mu \mathrm{g} / \mathrm{mL}$ & $50 \mu \mathrm{g} / \mathrm{mL}$ & $100 \mu \mathrm{g} / \mathrm{mL}$ & $200 \mu \mathrm{g} / \mathrm{mL}$ & $400 \mu \mathrm{g} / \mathrm{mL}$ \\
\hline NAPE & $11.84 \pm 0.61$ & $15.35 \pm 1.27$ & $20.61 \pm 0.93$ & $22.02 \pm 0.93$ & $24.12 \pm 1.95$ \\
NACE & $18.51 \pm 1.27$ & $21.67 \pm 1.95$ & $26.58 \pm 0.61$ & $33.6 \pm 0.93$ & $42.72 \pm 0.35$ \\
NAME & $29.04 \pm 1.27$ & $35.7 \pm 0.35$ & $39.56 \pm 0.35$ & $48.68 \pm 0.61$ & $60.26 \pm 0.61$ \\
\hline - & $10 \mu \mathrm{g} / \mathrm{mL}$ & $20 \mu \mathrm{g} / \mathrm{mL}$ & $40 \mu \mathrm{g} / \mathrm{mL}$ & $60 \mu \mathrm{g} / \mathrm{mL}$ & $80 \mu \mathrm{g} / \mathrm{mL}$ \\
\hline Ascorbic acid & $40.61 \pm 0.7$ & $48.33 \pm 1.27$ & $53.6 \pm 0.93$ & $64.12 \pm 0.93$ & $79.91 \pm 0.35$ \\
\hline
\end{tabular}

NAPE: N. alba petroleum ether extract; NACE: N. alba chloroform extract; NAME: N. alba methanol extract 
result obtained from group-I. Glibenclamide $(2.5 \mathrm{mg} / \mathrm{kg})$ along with NAME (400 mg/kg) exhibited a reduction of blood glucose concentrations to a maximum after 30 minutes of glucose administration $(121.1 \pm 1.6 \mathrm{mg} / \mathrm{dL}$, $127.61 \pm 1.67$, respectively).

\section{Effect on Bodyweight}

Bodyweight of group-II diabetic control rats was reduced remarkably, in contrast to group-I (normal control) and treated groups III to $\mathrm{V}$, as given in Table 4. The normal control group was observed to have a mean weight of $178.83 \pm 1.54$ grams at the beginning of the study that got raised to $189.56 \pm 1.63$ grams after 21 days. Bodyweight of group-II rats was significantly and sequentially reduced from $187.67 \pm 1.48$ to $141.81 \pm 1.03$ grams from beginning to the end of the study. The mean body weight in group-III at day 1 was $191 \pm 2.73$ grams, while these values were $195.55 \pm 3.08,209.24 \pm 3.3$, and $206.28 \pm 2.95$ grams on the $7 \mathrm{th}, 14 \mathrm{th}$, and 21st day, respectively. $400 \mathrm{mg} / \mathrm{kg}$ NAME showed a remarkable rise in body weight from $185.75 \pm 1.71$ to $209.9 \pm 1.94$ grams.

\section{STZ-induced Diabetic Study}

The remarkable rise of blood glucose was analyzed in diabetic control (group-II) animals in contrast to the groups-I, and III to V. In normal control (group-I), mean blood glucose was $103.66 \pm 3.31 \mathrm{mg} / \mathrm{dL}$ on the 1 st day and $109.33 \pm 2.35 \mathrm{mg} / \mathrm{dL}$ on the $21 \mathrm{st}$ day. In group-II (diabetic control), blood glucose level on the 1 st day was
$269.67 \pm 3.31 \mathrm{mg} / \mathrm{dL}$ and increased to $305.83 \pm 2.91 \mathrm{mg} /$ $\mathrm{dL}$ on the 21 st day. The mean body glucose in group-III at day 1 was $270.17 \pm 3.02 \mathrm{mg} / \mathrm{dL}$, while these values were $121.58 \pm 1.36,113.47 \pm 1.27$, and $108.07 \pm 1.21 \mathrm{mg} /$ $\mathrm{dL}$ on the $7 \mathrm{th}, 14 \mathrm{th}$, and 21 st day, respectively. NAME exhibited a comparable fall in blood glucose levels in contrast to the result obtained from diabetic animals. Animals administered $400 \mathrm{mg} / \mathrm{kg}$ of NAME reflected a fall in blood glucose from $264 \pm 3.06$ to $137.19 \pm 1.56$; details are given in Table 5.

\section{Biochemical Parameter}

There was a marked increase in all the biochemical parameters except HDL in group-II (Diabetic control). Standard drug glibenclamide $(2.5 \mathrm{mg} / \mathrm{kg})$ effectively controlled the levels of all the biochemical parameters. Doses of NAME $400 \mathrm{mg} / \mathrm{kg}$ were more effective than NAME $200 \mathrm{mg} / \mathrm{kg}$ in decreasing cholesterol levels and enhancing HDL level (Table 6). 21 days of NAME administration caused a remarkable reduction of SGOT, SGPT, serum creatinine, and serum urea level, in a dose-dependent manner of diabetic animals.

\section{Histopathology}

Microscopic structural alterations in the pancreas of experimental animals are shown in Fig. 3. The pancreas of normal rats has normal exocrine acinar tissues and endocrine $\beta$-cells, shown in Fig. 3A. On the contrary, histopathology of the pancreas of diabetic control group

Table 3: OGTT study results of $N$. alba methanol extract

\begin{tabular}{|c|c|c|c|c|c|}
\hline \multirow{2}{*}{$\begin{array}{l}\text { Groups } \\
n=6\end{array}$} & \multirow[b]{2}{*}{ Treatment } & \multicolumn{4}{|c|}{ Glucose concentration $(\mathrm{mg} / \mathrm{dL})$} \\
\hline & & $0 \mathrm{~min}$ & $30 \mathrm{~min}$ & $60 \mathrm{~min}$ & $120 \mathrm{~min}$ \\
\hline I & Normal control & $98.83 \pm 1.77$ & $145.71 \pm 2.73$ & $129.83 \pm 1.53$ & $118.33 \pm 0.87$ \\
\hline II & $\begin{array}{l}\text { Glibenclamide } \\
(2.5 \mathrm{mg} / \mathrm{kg})\end{array}$ & $100.91 \pm 1.34$ & $121.1 \pm 1.6^{* * *}$ & $111.01 \pm 1.47^{* * *}$ & $105.96 \pm 1.4^{* * *}$ \\
\hline III & NAME 200 & $100.14 \pm 1.41$ & $135.19 \pm 1.91^{* *}$ & $118.6 \pm 2.13^{* * *}$ & $113.66 \pm 2.04$ \\
\hline IV & NAME 400 & $98.16 \pm 1.28$ & $127.61 \pm 1.67^{* * *}$ & $112.89 \pm 1.47^{* * *}$ & $110.92 \pm 1.45^{*}$ \\
\hline
\end{tabular}

Readings represented as mean \pm standard error mean $(n=6) ;{ }^{*} \mathrm{p}<0.05 ;{ }^{* *} \mathrm{p}<0.01 ;{ }^{* * *} \mathrm{p}<0.001$, in comparison to normal control animals (one-way ANOVA with Dunnet's t test); NAME: N. alba methanol extract

Table 4: Liver, pancreas, and bodyweight analysis of rats after treatment with NAME

\begin{tabular}{|c|c|c|c|c|c|c|c|}
\hline \multirow{2}{*}{$\begin{array}{l}\text { Groups } \\
n=6\end{array}$} & \multirow[b]{2}{*}{ Treatment } & \multicolumn{4}{|c|}{ Bodyweight (gm) } & \multirow{2}{*}{$\begin{array}{l}\text { Liver weight } \\
\text { (g) }\end{array}$} & \multirow{2}{*}{$\begin{array}{l}\text { Pancreas } \\
\text { weight }(g)\end{array}$} \\
\hline & & 1st day & 7th day & 14th day & 21st day & & \\
\hline I & $\begin{array}{l}\text { Normal control + } 0.1 \mathrm{~mL} \\
\text { vehicle }\end{array}$ & $178.83 \pm 1.54^{*}$ & $185.37 \pm 1.76^{*}$ & $185.9 \pm 1.6^{* * *}$ & $189 \pm 1.63^{* * *}$ & $5.4 \pm 0.06^{* * *}$ & $0.84 \pm 0.03^{* * *}$ \\
\hline II & $\begin{array}{l}\text { Diabetic control + } 0.1 \mathrm{~mL} \\
\text { vehicle }\end{array}$ & $187.67 \pm 1.48$ & $175.43 \pm 1.57$ & $157.9 \pm 1.2$ & $141.81 \pm 1.03$ & $4.05 \pm 0.04$ & $0.99 \pm 0.03$ \\
\hline III & $\begin{array}{l}\text { Diabetic + glibenclamide } \\
(2.5 \mathrm{mg} / \mathrm{kg})\end{array}$ & $191 \pm 2.73$ & $195.55 \pm 3.08^{* * *}$ & $209.24 \pm 3.3^{* * *}$ & $206.28 \pm 2.95^{* * *}$ & $5.45 \pm 0.04^{* * *}$ & $0.86 \pm 0.03^{* * *}$ \\
\hline IV & $\begin{array}{l}\text { Diabetic + NAME } \\
(200 \mathrm{mg} / \mathrm{kg})\end{array}$ & $186.82 \pm 2.07$ & $200.4 \pm 2.26^{* * *}$ & $205.5 \pm 2.28^{* * *}$ & $216.43 \pm 2.44^{* * *}$ & $5.13 \pm 0.05^{* * *}$ & $0.8 \pm 0.01^{* * *}$ \\
\hline V & $\begin{array}{l}\text { Diabetic }+ \\
\text { NAME }(400 \mathrm{mg} / \mathrm{kg})\end{array}$ & $185.75 \pm 1.71$ & $198.75 \pm 1.83^{* * *}$ & $202.47 \pm 1.87^{* * *}$ & $209.9 \pm 1.94^{* * *}$ & $4.98 \pm 0.05^{* * *}$ & $0.83 \pm 0.01^{* * *}$ \\
\hline
\end{tabular}

Readings represented as mean \pm standard error mean $(n=6) ;{ }^{*} p<0.05 ;{ }^{* *} \mathrm{p}<0.01{ }^{* * *} \mathrm{p}<0.001$, in comparison to diabetic control animals (one-way ANOVA with Dunnet's t test); NAME: N. alba methanol extract 
Gurvirender Singh et al.

Table 5: Blood glucose levels of rats treated with NAME and standard drug

\begin{tabular}{|c|c|c|c|c|c|}
\hline \multirow{2}{*}{$\begin{array}{l}\text { Groups } \\
n=6\end{array}$} & \multirow[b]{2}{*}{ Treatment } & \multicolumn{4}{|c|}{ Fasting blood glucose $(\mathrm{mg} / \mathrm{dL})$} \\
\hline & & 1st day & 7th day & 14th day & 21st day \\
\hline I & Normal control + $0.1 \mathrm{~mL}$ vehicle & $103.66 \pm 3.31^{* * *}$ & $109.83 \pm 1.7^{* * *}$ & $107.16 \pm 3.02^{* * *}$ & $109.33 \pm 2.35^{* * *}$ \\
\hline II & Diabetic control $+0.1 \mathrm{~mL}$ vehicle & $271.67 \pm 3.31$ & $285.5 \pm 1.52$ & $296.67 \pm 1.74$ & $305.83 \pm 2.91$ \\
\hline III & $\begin{array}{l}\text { Diabetic + glibenclamide } \\
(2.5 \mathrm{mg} / \mathrm{kg})\end{array}$ & $270.17 \pm 3.02$ & $121.58 \pm 1.36^{* * *}$ & $113.47 \pm 1.27^{* * *}$ & $108.07 \pm 1.21^{* * *}$ \\
\hline IV & Diabetic + NAME (200 mg/kg) & $269.66 \pm 2.59$ & $219.5 \pm 3.83^{* * *}$ & $215.73 \pm 2.07^{* * *}$ & $210.34 \pm 2.02^{* * *}$ \\
\hline $\mathrm{V}$ & Diabetic + NAME (400 mg/kg) & $264 \pm 3.06$ & $161.4 \pm 1.83^{* * *}$ & $147.95 \pm 1.68^{* * *}$ & $137.19 \pm 1.56^{* * *}$ \\
\hline
\end{tabular}

Readings represented as mean \pm standard error mean $(n=6) ;{ }^{*} p<0.05 ;{ }^{* *} p<0.01 ;{ }^{* * *} p<0.001$, in comparison to diabetic control animals (one-way ANOVA with Dunnet's t test); NAME: N. alba methanol extract

Table 6: Effect of NAME biochemical parameter of diabetic rats

\begin{tabular}{llllll}
\hline & $\begin{array}{l}\text { Normal control }+ \\
\text { Parameters }\end{array}$ & $\begin{array}{l}\text { Diabetic control + } \begin{array}{l}\text { Diabetic }+ \text { glibenclamide } \\
0.1 \mathrm{~mL} \text { vehicle }\end{array} \\
(2.5 \mathrm{mg} / \mathrm{kg})\end{array}$ & $\begin{array}{l}\text { Diabetic }+ \text { NAME } \\
(200 \mathrm{mg} / \mathrm{kg})\end{array}$ & $\begin{array}{l}\text { Diabetic }+ \text { NAME } \\
(400 \mathrm{mg} / \mathrm{kg})\end{array}$ \\
\hline Total cholesterol (mg/dL) & $99.15 \pm 1.79^{* * *}$ & $237.96 \pm 4.3$ & $112.54 \pm 2.03^{* * *}$ & $151.7 \pm 2.74^{* * *}$ & $125.92 \pm 2.28^{* * *}$ \\
Triglycerides (mg/dL) & $77.87 \pm 0.95^{* * *}$ & $179.09 \pm 2.19$ & $84.87 \pm 1.04^{* * *}$ & $147.95 \pm 1.81^{* * *}$ & $100.45 \pm 1.23^{* * *}$ \\
HDL (mg/dL) & $47.4 \pm 0.78^{* * *}$ & $27.44 \pm 0.45$ & $49.77 \pm 0.82^{* * *}$ & $40.29 \pm 0.67^{* * *}$ & $35.55 \pm 0.59^{* * *}$ \\
LDL (mg/dL) & $36.18 \pm 2.18^{* * *}$ & $174.7 \pm 4.61$ & $45.79 \pm 2.43^{* * *}$ & $81.82 \pm 3.1^{* * *}$ & $70.28 \pm 2.57^{* * *}$ \\
VLDL (mg/dL) & $15.57 \pm 0.19^{* * *}$ & $35.82 \pm 0.44$ & $16.97 \pm 0.21^{* * *}$ & $29.59 \pm 0.36^{* * *}$ & $20.09 \pm 0.25^{* * *}$ \\
SGOT (IU/L) & $34.97 \pm 1.24^{* * *}$ & $74.3 \pm 2.65$ & $41.96 \pm 1.49^{* * *}$ & $57.7 \pm 2.05^{* * *}$ & $44.43 \pm 1.58^{* * *}$ \\
SGPT (IU/L) & $24.75 \pm 1.03^{* * *}$ & $77.97 \pm 3.23$ & $32.18 \pm 1.33^{* * *}$ & $44.56 \pm 1.85^{* * *}$ & $37.87 \pm 1.57^{* * *}$ \\
Creatinine (mg/dL) & $0.47 \pm 0.05^{* * *}$ & $0.98 \pm 0.11$ & $0.56 \pm 0.06^{* *}$ & $0.89 \pm 0.1$ & $0.67 \pm 0.07^{*}$ \\
Serum urea (mg/dL) & $34.55 \pm 0.55^{* * *}$ & $107.12 \pm 1.7$ & $38.01 \pm 0.6^{* * *}$ & $72.56 \pm 1.15^{* * *}$ & $64.58 \pm 1.03^{* * *}$ \\
\hline
\end{tabular}

Readings represented as mean \pm standard error mean $(\mathrm{n}=6) ;{ }^{*} \mathrm{p}<0.05 ;{ }^{* *} \mathrm{p}<0.01 ;{ }^{* * *} \mathrm{p}<0.001$, in comparison to diabetic control animals (one-way ANOVA with Dunnet's t test); NAME: N. alba methanol extract

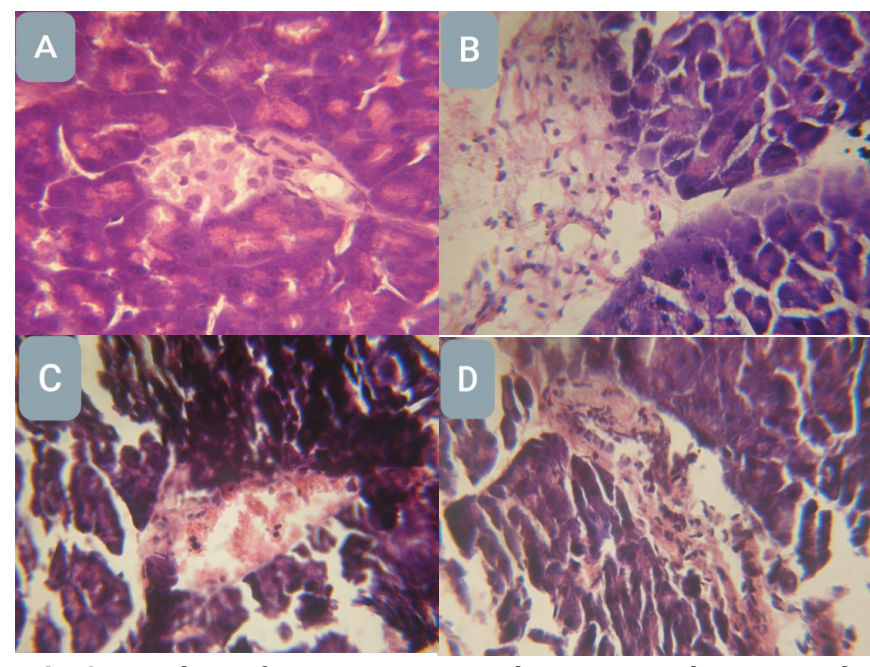

Fig. 3: Histology of pancreas; A-Normal group; B-Diabetic control; C-NAME $200 \mathrm{mg} / \mathrm{kg}$ treated; D-NAME $400 \mathrm{mg} / \mathrm{kg}$ treated

rats exhibited degranulation and disruption of the cell of islets of Langerhans (Fig. 3B). However, NAME 200 and $400 \mathrm{mg} / \mathrm{kg}$ treated animals were observed to have a better shape of tissue of the pancreas, as shown in Figs 3C and D.

\section{DISCUSSION}

The rationale of the whole study was to trace out antidiabetic tendencies of $N$. alba pre-clinically and by $\alpha$-amylase and $\alpha$-glucosidase. Different methods were employed for the determination of goals, including in vitro and in vivo studies. In in vitro $\alpha$-amylase and $\alpha$-glucosidase brought foundation for the whole study by substantiating the antidiabetic potential of $N$. alba methanol extract over petroleum ether or chloroform extract. Further, in vivo study results provided the testimony of $N$. alba leaves methanol extract to possess antidiabetic potentials. Diabetic rats administered with 200 and $400 \mathrm{mg} / \mathrm{kg}$ of NAME gave comparable results to the group administered standard glibenclamide $(2.5 \mathrm{mg} / \mathrm{kg})$, in reducing blood glucose levels. Moreover, the results of other biochemical parameters, like total cholesterol, triglycerides, HDL, SGOT, SGPT, urea, and creatinine reflected a better picture in contrast to that of the control group. In addition, histopathological observations also indicate the activity of $N$. alba in the maintenance of the diabetic condition. Also, the antioxidant nature of the $N$. alba extracts, by DPPH and hydrogen peroxide assays, indicates the role of this plant in diabetes. Subsequently, even more research is required to analyze the molecular mechanism involved in the tendency of $N$. alba in the reduction and control of hyperglycemia.

\section{REFERENCES}

1. Rains, Justin L, Jain SK. Oxidative stress, insulin signaling, and diabetes. Free Radical Biology and Medicine. 2011;50(5):567-575. 
2. Kharroubi AT, Darwish HM. Diabetes mellitus: The epidemic of the century. World journal of diabetes. 2015;6(6):850.

3. Ahmed AM. History of diabetes mellitus. Saudi medical journal. 2002; 23 (4): 373-378.

4. Wang Z, Zhao X, Liu X, Lu W, Jia S, Hong T, Li R, Zhang H, Peng L, Zhan $X$. Anti-diabetic activity evaluation of a polysaccharide extracted from Gynostemma pentaphyllum. International journal of biological macromolecules. 2019; 126:209-214.

5. Maheshwari RA, Khatri K, Sailor GU, Balaraman R. Antidiabetic activity of Dibolin (a polyherbal formulation) in streptozotocinnicotinamide induced type 2 diabetic rats. Int J Pharm Pharm Sci. 2014;2:893-897.

6. Verspohl EJ. Novel pharmacological approaches to the treatment of type 2 diabetes. Pharmacological reviews. 2012; 64(2):188-237.

7. Balunas MJ, Kinghorn AD. Drug discovery from medicinal plants. Life sciences. 2005; 78(5):431-441.

8. Dixon RA. Engineering of plant natural product pathways. Current opinion in plant biology. 2005; 8(3):329-336.

9. Sabu MC, Kuttan R. Anti-diabetic activity of medicinal plants and its relationship with their antioxidant property. Journal of ethnopharmacology. 2002; 81(2):155-160.

10. Ekor M. The growing use of herbal medicines: issues relating to adverse reactions and challenges in monitoring safety. Frontiers in pharmacology. 2014; 4:177.

11. Azadbakhta M, Safapour S, Ahmadi A, Ghasemi M, Shokrzadeh M. Anti-diabetic effects of aqueous fruits extract of Diospyros lotus L. on streptozotocin-induced diabetic rats and the possible morphologic changes in the liver, kidney, and heart. Journal of Pharmacognosy and Phytotherapy. 2010;2(2):010-016.

12. World Health Organization. WHO Expert Committee on Diabetes Mellitus [meeting held in Geneva from 25 September to 1 October 1979]: second report. World Health Organization; 1980.

13. Tiwari AK, Rao JM. Diabetes mellitus and multiple therapeutic approaches of phytochemicals: Present status and future prospects. Current science. 2002:30-38.

14. Bose A, Sahoo M, Ray SD. In vivo evaluation of anti-diarrheal activity of the rhizome of Nymphaea alba (Nymphaeaceae). Oriental Pharmacy and Experimental Medicine. 2012; 12(2):129-134.

15. Nazir S, Qureshi MA, Chat OA. Anti-tumor, Anti-oxidant and Antimicrobial potential of Nymphaea alba and Nymphaea mexicana flowers-a comparative study. Adv. Biomed. Pharma. 2015;2: 196-204.

16. Karthikeyan R. Anti-Inflammatory Activity of Flowers of Nymphaea alba by HRBC Membrane Stabilization Method. Research in Plant Biology. 2015;5(4).

17. Heslop-Harrison Y. Nymphaea L. Journal of Ecology. 1955;43(2): 719-734.

18. Lakshmi T, Madhusudhanan N, Rajendran R. Nymphaea alba Linn.-An Overview. Research journal of Pharmacy and Technology. 2013; 6(9):974-977.

19. Sumlu S, Atar HH, Khawar KM. Breaking seed dormancy of water lily (Nymphaea alba L.) under in vitro conditons. Biotechnology \& Biotechnological Equipment. 2010;24(1):1582-1586.

20. Kłosowski S, Tomaszewicz H. Habitat conditions of the Nymphaeetum candidae Miljan 1958 and Nupharo-Nymphaeetum albae Tomaszewicz 1977 dominated by Nymphaea alba. Acta Societatis Botanicorum Poloniae. 1989; 58(4):613-624.

21. Bose A, Ray SD, Sahoo M. Central depressant activity of ethanol extract of Nymphaea alba rhizome in mice. Oriental Pharmacy and Experimental Medicine. 2013; 13(2):159-64.

22. Rajagopal K, Sasikala K, Ragavan B. Hypoglycemic and antihyperglycemic activity of Nymphaea stellata flowers in normal and alloxan diabetic rats. Pharmaceutical Biology. 2008 46(9):654-659.

23. Rajagopal K, Sasikala K. Antidiabetic activity of hydro-ethanolic extracts of Nymphaea Stellata flowers in normal and alloxan induced diabetic rats. African journal of pharmacy and pharmacology. 2008; 2(8):173-178.

24. Rahuja N, Mishra A, Gautam S, Tamrakar AK, Maurya R, Jain SK, Srivastava AK. Antidiabetic activity in flowers of Nymphaea rubra. Int J Pharm Sci Rev Res. 2013;22(24):121-133.

25. National Research Council. Guide for the care and use of laboratory animals. National Academies Press; 2010.

26. Ali H, Houghton PJ, Soumyanath A. $\alpha$-Amylase inhibitory activity of some Malaysian plants used to treat diabetes; with particular reference to Phyllanthus amarus. Journal of ethnopharmacology. 2006;107(3):449-55.

27. Sudha P, Zinjarde SS, Bhargava SY, Kumar AR. Potent $\alpha$-amylase inhibitory activity of Indian Ayurvedic medicinal plants. BMC complementary and alternative medicine. 2011; 11(1):5.

28. Feng J, Yang XW, Wang RF. Bio-assay guided isolation and identification of $\alpha$-glucosidase inhibitors from the leaves of Aquilaria sinensis. Phytochemistry. 2011;72(2-3):242-247.

29. Rani A, Kumar S, Khar RK. In Vitro Antidiabetic and Hypolipidemic Activity of Selected Medicinal Plants.

30. Dhalwal K, Deshpande YS, Purohit AP, Kadam SS. Evaluation of the Antioxidant Activity of Sida cordifolia. Pharmaceutical biology. 2005;43(9):754-761.

31. NabaviSM, Ebrahimzadeh MA, Nabavi SF, Hamidinia A, Bekhradnia AR. Determination of antioxidant activity, phenol and flavonoids content of Parrotia persica Mey. Pharmacologyonline. 2008;2:560-567.

32. Verma A, Jana GK, Sen S, Chakraborty R, Sachan S, Mishra A. Pharmacological evaluation of Saraca indica leaves for central nervous system depressant activity in mice. J Pharm Sci Res. 2010;2(6):338-343.

33. Pandit R, Phadke A, Jagtap A. Antidiabetic effect of Ficus religiosa extract in streptozotocin-induced diabetic rats. Journal of ethnopharmacology. 2010;128(2):462-466.

34. Thippeswamy BS, Mishra B, Veerapur VP, Gupta G. Anxiolytic activity of Nymphaea alba Linn. in mice as experimental models of anxiety. Indian journal of pharmacology. 2011;43(1):50.

35. Barik R, Jain S, Qwatra D, Joshi A, Tripathi GS, Goyal R. Antidiabetic activity of aqueous root extract of Ichnocarpus frutescens in streptozotocin-nicotinamide induced type-II diabetes in rats. Indian Journal of Pharmacology. 2008;40(1):19.

36. Kaushik P, Kaushik D, Khokra SL, Sharma A. Antidiabetic activity of the plant Abutilon indicum in streptozotocin-induced experimental diabetes in rats. Int. J. Pharmacog. Phytochem. Res. 2010;2:45-49.

37. Muruganandan S, Srinivasan K, Gupta S, Gupta PK, Lal J. Effect of mangiferin on hy perglycemia and atherogenicity in streptozotocin diabetic rats. Journal of ethnopharmacology. 2005; 97(3):497-501.

38. Aslan M, Orhan DD, Orhan N, Sezik E, Yesilada E. In vivo antidiabetic and antioxidant potential of Helichrysum plicatum ssp. Plicatum capitulums in streptozotocin-induced-diabetic rats. Journal of ethnopharmacology. 2007;109(1):54-59.

39. Seedevi P, Ganesan AR, Moovendhan M, Mohan K, Sivasankar P, Loganathan S, Vairamani S, Shanmugam A. Anti-diabetic activity of crude polysaccharide and rhamnose-enriched polysaccharide from G. lithophila on Streptozotocin (STZ)-induced in Wistar rats. Scientific Reports. 2020 Jan 17;10(1):1-2.

40. Nayak Y, Hillemane V, Daroji VK, Jayashree BS, Unnikrishnan MK. Antidiabetic activity of benzopyrone analogues in nicotinamideStreptozotocin induced Type 2 diabetes in rats. The Scientific World Journal. 2014. 